\title{
Treatment of atopic dermatitis with cyclosporin A: a case report
}

\section{Zastosowanie cyklosporyny A w terapii atopowego zapalenia skóry - opis przypadku}

\author{
Karolina Kaaz', Adam Reich ${ }^{1,2}$ \\ 'Department of Dermatology, Venereology and Allergology, Wroclaw Medical University, Poland \\ 2Department of Dermatology, University of Rzeszow, Poland \\ 'Katedra i Klinika Dermatologii, Wenerologii i Alergologii Uniwersytetu Medycznego we Wrocławiu, Polska \\ 2Zakład i Klinika Dermatologii, Uniwersytet Rzeszowski, Polska
}

Dermatol Rev/Przegl Dermatol 2017, 104, 432-438

DOI: https://doi.org/l0.5। |4/dr.2017.69950

\author{
CORRESPONDING AUTHOR/ \\ ADRES DO KORESPONDENCJI: \\ dr hab. med. Adam Reich, \\ prof. nadzw. \\ Zakład i Klinika Dermatologii \\ Uniwersytet Rzeszowski \\ ul. Szopena 2, 35-055 Rzeszów \\ tel.: +48 605076722 \\ e-mail: adi_medicalis@go2.pl
}

\begin{abstract}
Introduction. Despite the progress that has been made in the therapy of atopic dermatitis in recent years, cyclosporin A remains the first-line treatment of severe forms of the disease.

Objective. To present a case of effective cyclosporin A therapy of severe atopic dermatitis with features of secondary bacterial infection.

Case report. A 22-year-old man was admitted to hospital with extensive erythematous-desquamative skin lesions. The lesions were accompanied by intense itching. Based on the patient's medical history, physical examination, laboratory test results and histological examination of a skin biopsy, atopic dermatitis with bacterial superinfection was diagnosed. Treatment with cyclosporin A in combination with antibiotics was initiated, resulting in significant clinical improvement within a few days after the initiation of therapy.

Conclusions. Our case confirms that cyclosporin A is a fast-acting and highly effective therapeutic agent in atopic dermatitis, and the risk of adverse reactions, if the drug is used properly, is low.
\end{abstract}

\section{STRESZCZENIE}

Wprowadzenie. Mimo postępu, jaki dokonał się w ostatnich latach $\mathrm{w}$ terapii atopowego zapalenia skóry, leczeniem pierwszego wyboru ciężkich postaci tej choroby nadal jest cyklosporyna A.

Cel pracy. Przedstawienie skutecznej terapii ciężkiego atopowego zapalenia skóry z cechami wtórnego nadkażenia bakteryjnego cyklosporyną A.

Opis przypadku. Mężczyzna 22-letni został przyjęty do szpitala z powodu rozległych zmian rumieniowo-złuszczających. Zmianom skórnym towarzyszył intensywny świąd. Na podstawie wywiadu, badania fizykalnego, wyników badań laboratoryjnych oraz badania histologicznego wycinka skóry u pacjenta rozpoznano atopowe zapalenie skóry z cechami wtórnego nadkażenia bakteryjnego i rozpoczęto leczenie cyklosporyną A z antybiotykoterapią, uzyskując znaczącą poprawę kliniczną w ciągu kilku dni.

Wnioski. Przedstawiony przypadek potwierdza, że cyklosporyna A cechuje się szybkim działaniem i dużą skutecznością, a ryzyko wystąpienia działań niepożądanych, jeśli lek jest stosowany właściwie, jest małe.

Key words: atopic dermatitis, treatment, secondary infection.

Słowa kluczowe: atopowe zapalenie skóry, leczenie, wtórne zakażenie. 


\section{INTRODUCTION}

Atopic dermatitis (AD) is a chronic recurrent inflammatory disease of the skin characterized by the presence of typically localized eczematous skin lesions accompanied by intense itching. Atopic dermatitis may coexist with other IgE-associated atopic diseases including allergic rhinitis, allergic conjunctivitis, food allergy and bronchial asthma. The pathogenesis of atopic dermatitis involves genetic, epigenetic, immunological and environmental factors. One of the main factors predisposing to the development of AD is defective epidermal barrier, especially mutations in the filaggrin gene [1]. In recent years, attention has turned to the effect of environmental contamination, particularly exposure to toluene and other hydrocarbons, on the increase in AD incidence observed in developed countries [2-5].

Atopic dermatitis is diagnosed on the basis of established diagnostic criteria. In Poland, the criteria proposed by Hanifin and Rajka are the most commonly used [6]. Based on these criteria, to be diagnosed with $\mathrm{AD}$, a patient must meet at least 3 out of 4 major criteria (pruritus, chronic and relapsing dermatitis, characteristic morphology and location of cutaneous lesions, personal or family history of atopic diseases) and 3 out of 23 minor criteria [6]. The treatment of AD is based primarily on topical glucocorticosteroids and calcineurin inhibitors. A crucial role is also played by regular skin care with emollients aimed at restoring the integrity of the epidermal barrier [7]. In a proportion of patients, however, the course of AD is so severe that systemic treatment is necessary. Although great advances have recently been made in AD therapy, and new interleukin-4 (IL-4) and/or IL-13 or IL-31 blockers (including dupilumab, tralokinumab, nemolizumab) have been developed [8-10], cyclosporin A remains the first-line drug for the treatment of severe AD [7].

\section{OBJECTIVE}

The aim of the study was to present a case of effective cyclosporin A treatment of severe AD with features of secondary bacterial superinfection of skin lesions, as a starting point for a discussion on immunosuppressive treatment in patients with AD.

\section{CASE REPORT}

A 22-year-old man, an upholsterer by profession, was admitted to the Department of Dermatology, Venereology and Allergology in Wroclaw with extensive erythematous-desquamative skin lesions. The first lesions appeared on the skin about 4 months prior to hospital admission. The patient reported intense skin itching (score of 7-8 in the 10-point Numeric Rating Scale (NRS)). The skin lesions were not accom-

\section{WPROWADZENIE}

Atopowe zapalenie skóry (AZS) jest przewlekłą i nawrotową chorobą zapalną skóry. Charakteryzuje się obecnością wypryskowych zmian skórnych o typowej lokalizacji, którym towarzyszy intensywny świąd. Atopowe zapalenie skóry może współwystępować z innymi atopowymi chorobami IgE-zależnymi, takimi jak alergiczny nieżyt nosa, alergiczne zapalenie spojówek, alergia pokarmowa oraz astma oskrzelowa. W patogenezie AZS biorą udział czynniki genetyczne, epigenetyczne, immunologiczne i środowiskowe. Jednym z podstawowych czynników predysponujących do rozwoju AZS jest defekt bariery naskórkowej, zwłaszcza mutacje w obrębie genu filagryny [1]. W ostatnich latach zaczęto zwracać uwagę na zanieczyszczenia środowiska, szczególnie na narażenie na toluen i inne węglowodory, i związany z tym wzrost liczby zachorowań na AZS w krajach rozwiniętych [2-5].

Rozpoznanie AZS ustala się na podstawie kryteriów diagnostycznych. W Polsce najczęściej stosowane są kryteria opracowane przez Hanifina i Rajkę [6]. Zgodnie z nimi, aby zdiagnozować AZS, pacjent musi spełniać przynajmniej 3 z 4 kryteriów głównych (świąd, przewlekły i nawrotowy przebieg schorzenia, charakterystyczna morfologia i lokalizacja zmian skórnych oraz osobniczy lub rodzinny wywiad atopowy) oraz 3 z 23 kryteriów mniejszych [6]. W terapii AZS mają zastosowanie przede wszystkim miejscowe glikokortykosteroidy oraz inhibitory kalcyneuryny. Bardzo istotna jest także regularna pielęgnacja skóry z wykorzystaniem emolientów w celu odbudowy bariery naskórkowej [7]. U części pacjentów przebieg AZS jest jednak na tyle ciężki, że konieczne jest zastosowanie leczenia ogólnego. Mimo dużego postępu w terapii AZS w ostatnich latach i opracowania nowych leków blokujących interleukinę 4 (IL-4) i/lub IL-13 czy też IL-31 (m.in. dupilumabu, tralokinumabu, nemolizumabu) [8-10], nadal leczeniem pierwszego wyboru w terapii ciężkiego AZS jest cyklosporyna A [7].

\section{CEL PRACY}

Celem niniejszej pracy było przedstawienie skutecznej terapii ciężkiego AZS z cechami wtórnego nadkażenia bakteryjnego zmian skórnych cyklosporyną A jako przyczynek do dyskusji nad problemem leczenia immunosupresyjnego chorych na AZS.

\section{OPIS PRZYPADKU}

Mężczyzna 22-letni, z zawodu tapicer, został przyjęty do Kliniki Dermatologii, Wenerologii i Alergologii we Wrocławiu z powodu rozległych zmian rumieniowo-złuszczających. Pierwsze zmiany skórne pojawiły się ok. 4 miesięcy przed przyjęciem do szpitala. Chory podawał nasilony świąd skóry, oce- 
panied by any other signs or symptoms. By taking the patient's history it was established that he had food protein allergy during early childhood. In addition, the patient had been suffering from allergic rhinitis for several years prior to hospitalization. Also, intradermal prick tests with airborne allergens performed on an outpatient basis were positive to grass pollens, house dust mites and cat hair. Aside from allergic rhinitis, the patient had no chronic diseases and took no medications on a permanent basis. Also, the patient had been a smoker for the past 2 years (daily consumption of ca. 20 cigarettes), but was not addicted to alcohol or psychoactive substances.

On the day of admission to the Department, the clinical picture was dominated by erythematous-desquamative and erythematous-papular lesions with features of lichenification, located primarily on the upper and lower extremities, neck and back (Figs. 1-3). Lichenification was also identified in areas of flexion.

During hospitalization a range of laboratory tests were performed (CBC with differential, basic biochemical tests, assessment of inflammato-

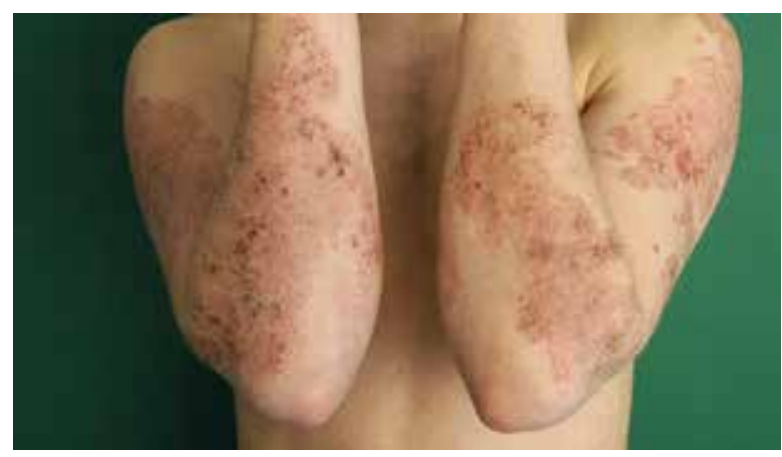

Figure I. Erythematous-desquamative lesions with features of secondary bacterial infection on the upper extremities

Rycina I. Zmiany rumienowo-złuszczające z cechami wtórnej infekcji bakteryjnej na kończynach górnych

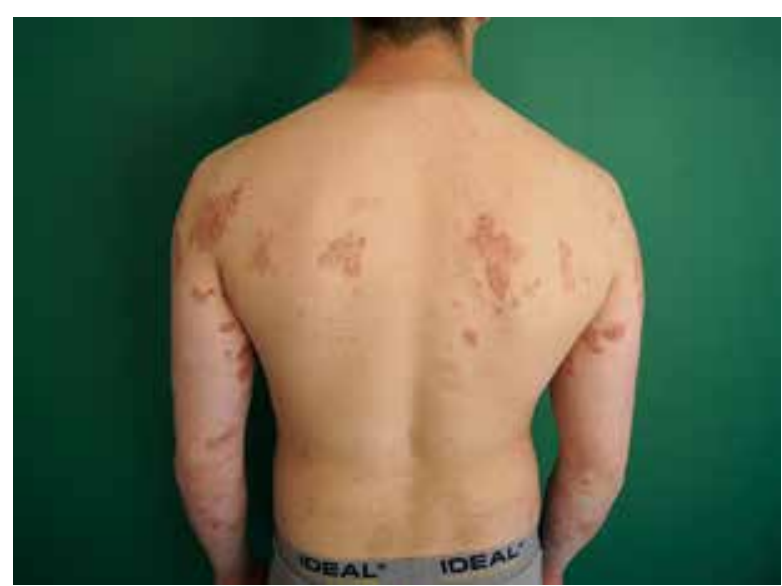

Figure 3. Skin lesions on the back

Rycina 3. Zmiany skórne na plecach niony na 7-8 pkt w 10-punktowej numerycznej skali szacunkowej NRS (Numeric Rating Scale). Zmianom skórnym nie towarzyszyły inne objawy subiektywne ani objawy ogólne. Na podstawie wywiadu ustalono, że u chorego w okresie wczesnego dzieciństwa występowała skaza białkowa. Ponadto od kilku lat chorował na alergiczny nieżyt nosa, a w wykonanych ambulatoryjnie śródskórnych testach typu prick $\mathrm{z}$ alergenami powietrznopochodnymi stwierdzono dodatni odczyn na pyłki traw, roztocze kurzu domowego oraz sierść kota. Poza alergicznym nieżytem nosa pacjent nie chorował przewlekle, nie przyjmował także żadnych leków na stałe. Ponadto chory od 2 lat palił ok. 20 papierosów dziennie, nie był natomiast uzależniony od alkoholu lub innych substancji psychoaktywnych.

W dniu przyjęcia do Kliniki w obrazie klinicznym przeważały zmiany rumieniowo-złuszczające i rumieniowo-grudkowe $\mathrm{z}$ cechami zliszajcowacenia zlokalizowane przede wszystkim w obrębie kończyn górnych i dolnych, a także na szyi i plecach (ryc. 1-3). Ponadto w okolicach zgięciowych obecna była lichenifikacja.

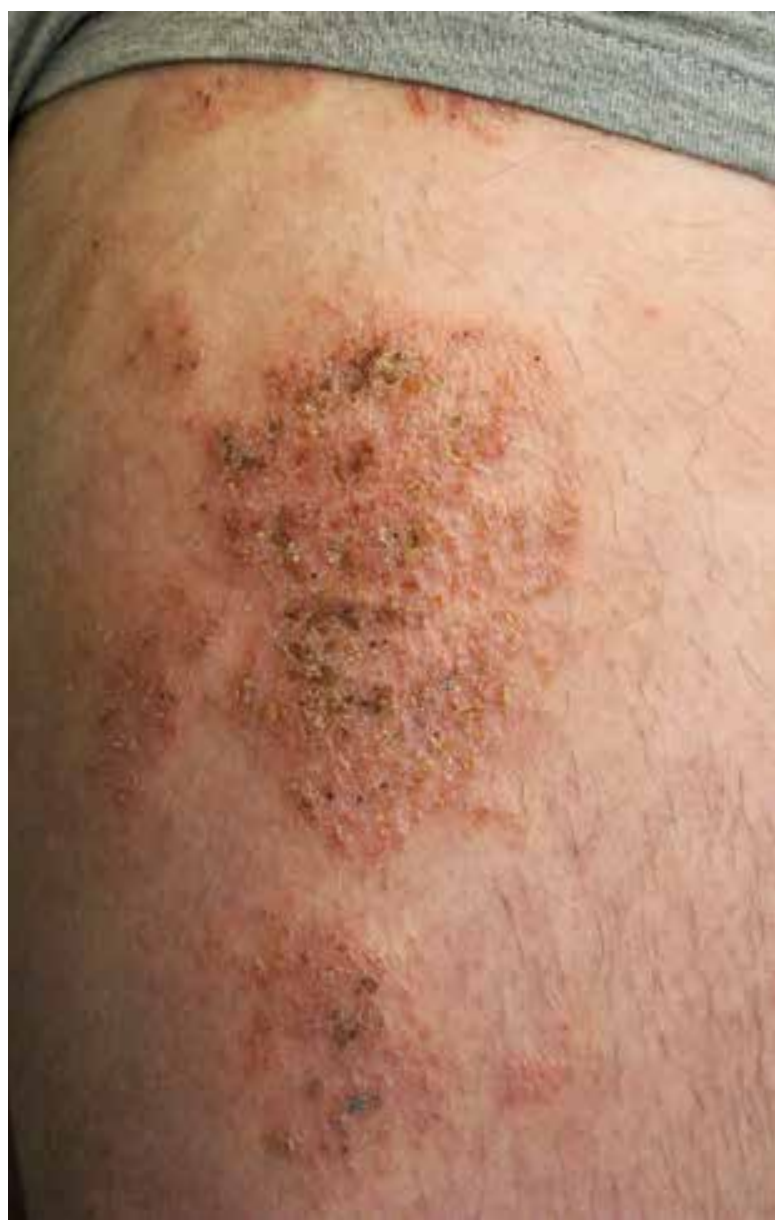

Figure 2. Close-up of skin lesions on the lower extremities

Rycina 2. Zbliżenie zmian skórnych na kończynach dolnych 
ry markers, general urine analysis, assessment of serum concentrations of C3 and C4 components of the complement system, ANA - antinuclear antibody test), which demonstrated no abnormalities. Total immunoglobiln E concentration was determined, which was within the limits of normal and amounted to $53 \mathrm{IU} / \mathrm{ml}$ (normal range: $<100 \mathrm{IU} / \mathrm{ml}$ ). To broaden the scope of dermatological diagnostics, a skin biopsy was taken to perform a histological examination, which showed hyperkeratosis, focal parakeratosis, acanthosis and papillomatosis, along with vacuolar degeneration of cells in the basal and spinous layers. The dermis demonstrated perivascular infiltrates dominated by lymphocytes and neutrophils, with a tendency to epidermotropism. The overall histological picture was suggestive of eczema. Direct immunofluorescence test (DIF) revealed no IgG, IgA, IgM, C1q and C3c deposits in the skin. Since no IgA antibodies against endomysium, gliadin and tissue transglutaminase were detected, and the result of DIF examination of skin biopsy was negative, Duhring's disease was ruled out. Based on the overall clinical picture of the disease and results of additional tests, the patient was diagnosed with AD with features of secondary bacterial infection.

Systemic antibiotic with oral cefuroxime was introduced at a dose of $500 \mathrm{mg}$ every $12 \mathrm{~h}$, combined with short-term intravenous hydrocortisone at a dose of up to $200 \mathrm{mg} /$ day and antihistamine drugs - levocetirizine at $10 \mathrm{mg} /$ day. Since no satisfactory improvement was observed, cyclosporin A at a dose of $250 \mathrm{mg} /$ day ( $3.8 \mathrm{mg} / \mathrm{kg}$ b.w.) in two divided doses was introduced on day 3 of hospitalization. The treatment led to a considerable improvement in the patient's clinical condition and successfully controlled skin lesions (Figs. 4-6). Following the patient's discharge, cyclosporin A treatment was continued together with topical application of prednisolone $0.5 \%$ ointment.

\section{DISCUSSION}

Cyclosporin A is a drug with a potent immunosuppressive activity which is used in the treatment of inflammatory diseases and in the prevention of transplant rejection. The drug inhibits T-cell activity and proliferation [11]. Cyclosporin A forms a complex with cyclophilin, a protein found in the cytosol which inhibits calcineurin. By inactivating calcineurin, cyclosporin A blocks the secretion of proinflammatory cytokines (e.g. IL-2) through the inhibition of the transcription factor NFAT (nuclear factor of activated T cells) [12]. As mentioned above, cyclosporin A is the firstline drug in the treatment of severe AD [13]. The drug is usually applied during periods of exacerbation. When satisfactory improvement is achieved, cyclo-
W trakcie hospitacji wykonano szereg badań laboratoryjnych (morfologia krwi z rozmazem, podstawowe badania biochemiczne, ocena wykładników stanu zapalnego, badanie ogólne moczu, ocena stężenia składowych C3 i C4 dopełniacza w surowicy, badanie na obecność przeciwciał przeciwjądrowych - ANA), w których nie wykazano żadnych nieprawidłowości. Oznaczono całkowite stężenie immunoglobuliny E (IgE), które mieściło się w granicach normy i wynosiło $53 \mathrm{IU} / \mathrm{ml}$ (norma: < $100 \mathrm{IU} / \mathrm{ml}$ ). W celu poszerzenia diagnostyki dermatologicznej pobrano próbkę ze zmian skórnych do badania histologicznego, w którym stwierdzono hiperkeratozę, ogniskową parakeratozę i akantozę oraz papillomatozę, a także zwyrodnienie wodniczkowe komórek warstwy podstawnej i kolczystej. W skórze właściwej obserwowano wokółnaczyniowe nacieki z przewagą limfocytów i neutrofilów, z tendencją do epidermotropizmu. Całość obrazu histologicznego przemawiała za wypryskiem. W bezpośrednim badaniu immuofluorescencyjnym (direct immunofluorescence - DIF) nie wykazano obecności złogów IgG, IgA, IgM, C1q i C3c w skórze. Na podstawie braku przeciwciał IgA przeciwko endomysium, przeciwko gliadynie i przeciwko transglutaminazie tkankowej oraz ujemnego badania DIF wycinka skóry wykluczono chorobę Duhringa. Ostatecznie, opierając się na całości obrazu chorobowego i wynikach badań dodatkowych, u chorego rozpoznano AZS z cechami wtórnej infekcji bakteryjnej.

W leczeniu zastosowano antybiotykoterapię ogólną cefuroksymem doustnie w dawce $500 \mathrm{mg}$ co 12 godzin, krótkotrwale hydrokortyzon dożylnie w dawce do $200 \mathrm{mg} /$ dobę oraz leki przeciwhistaminowe - lewocetyryzynę w dawce $10 \mathrm{mg} /$ dobę. Ze względu na brak zadowalającej poprawy w 3 . dobie hospitalizacji zdecydowano o włączeniu cyklosporyny A w dawce $250 \mathrm{mg} /$ dobę ( 3,8 mg/kg m.c.) w dwóch dawkach podzielonych. W wyniku zastosowanego leczenia uzyskano znaczną poprawę stanu klinicznego oraz kontrolę zmian skórnych (ryc. 4-6). Po wypisie ze szpitala kontynuowano leczenie cyklosporyną A oraz miejscową aplikację 0,5\% maści prednizolonowej.

\section{OMÓWIENIE}

Cyklosporyna A jest lekiem o silnym działaniu immunosupresyjnym stosowanym w leczeniu chorób zapalnych oraz w profilaktyce odrzucania przeszczepów. Lek hamuje aktywność oraz proliferację limfocytów T [11]. Cykloporyna A tworzy kompleks z białkiem cytozolu - cyklofiliną, która następnie hamuje kalcyneurynę. Cyklosporyna A, poprzez inaktywację kalcyneuryny, blokuje wydzielanie cytokin prozapalanych (m.in. IL-2) przez hamowanie jądrowego czynnika transkrypcyjnego NFAT (nuclear factor of activated T cells) [12]. Jak wspomniano, cyklosporyna A stanowi 


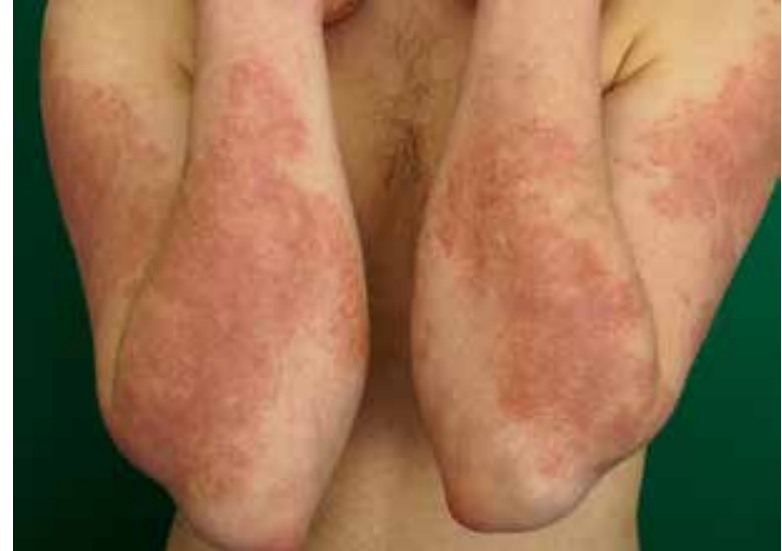

Figure 4. Skin lesions on the upper extremities 4 days after the initiation of cyclosporin A treatment

Rycina 4. Zmiany skórne na kończynach górnych po 4 dniach od rozpoczęcia leczenia cyklosporyną $A$

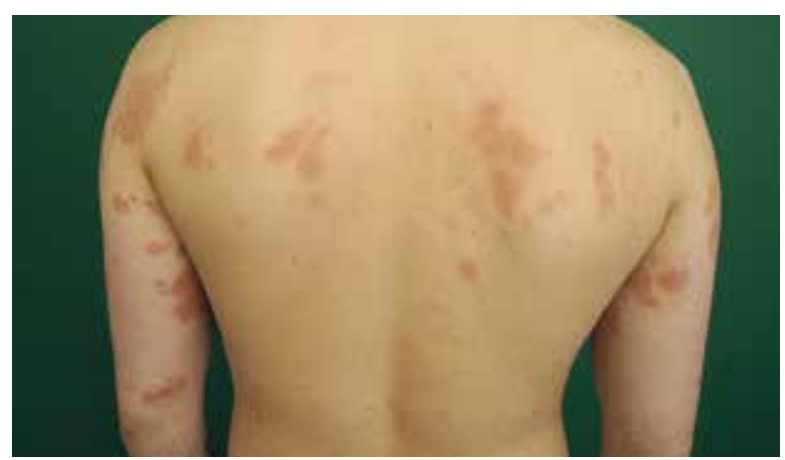

Figure 6. Skin lesions on the back 4 days after the initiation of cyclosporin A treatment

Rycina 6. Zmiany skórne na plecach po 4 dniach od rozpoczęcia leczenia cyklosporyna A

sporin A can be withdrawn, though topical treatment and appropriate skin care should still be continued. In cases of disease recurrence the drug can be re-introduced at the previously effective dose. Some patients may require maintenance therapy for a longer period ( $>6$ months).

Patients with AD have a predisposition for bacterial and viral infections. Aside from defective epidermal barrier, the main cause of these infections is currently believed to be a decrease in the production of antibacterial peptides (including $\beta$-defensin and human cathelicidin (LL-37) in the epidermis of AD patients $[14,15]$. This fact might raise concerns that the use of cyclosporin A, an immunosuppressive drug, in $\mathrm{AD}$ would significantly increase the risk of cutaneous infections. Studies conducted to date show, however, that cyclosporin A treatment of severe AD is safe both for adults and children, highly effective and capable of causing a significant improvement in the quality of life of patients $[16,17]$. As a rule, the therapeutic effect is evident already after 2 weeks of treatment [17]. Furthermore, in addition to its anti-inflammato-

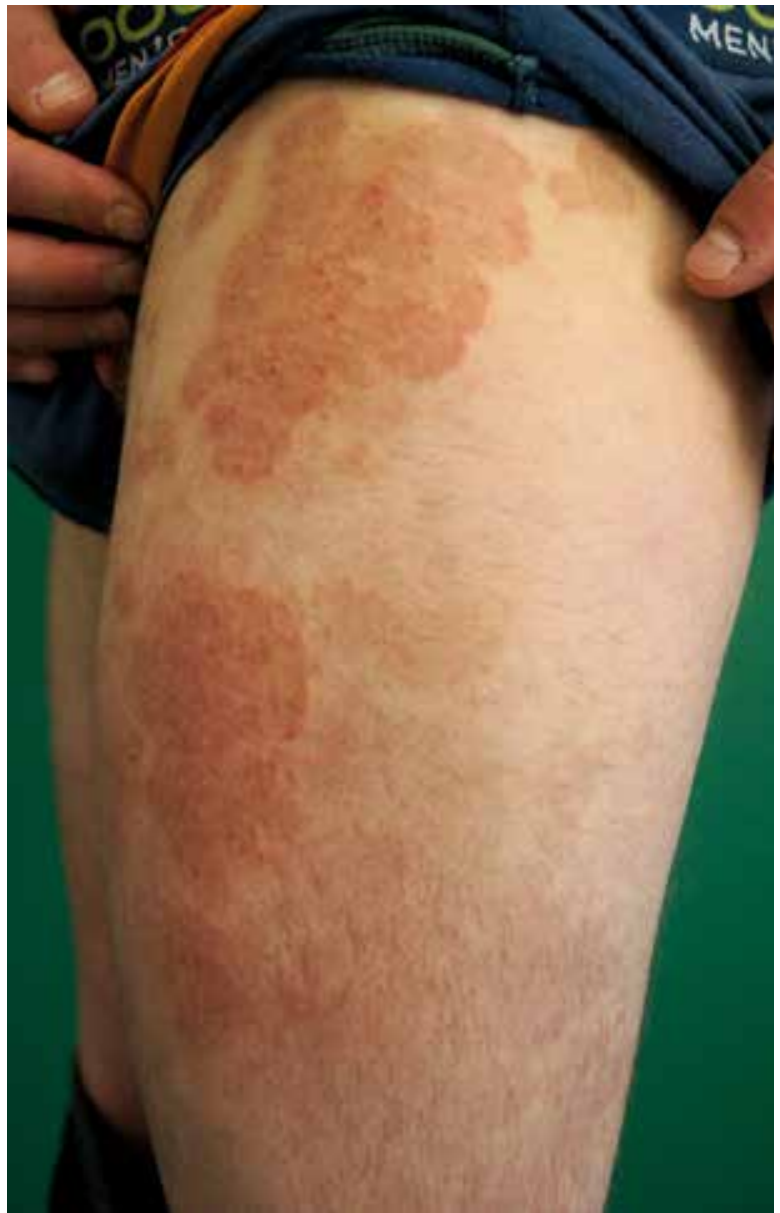

Figure 5. Close-up of skin lesions on the upper extremities 4 days after the initiation of cyclosporin A treatment

Rycina 5. Zbliżenie zmian na kończynach dolnych po 4 dniach od rozpoczęcia leczenia cyklosporyną $A$

pierwszą linię leczenia ciężkiego AZS [13]. Lek z reguły stosuje się w okresie zaostrzeń, natomiast po osiągnięciu zadowalającej poprawy podawanie cyklosporyny A można przerwać, jednocześnie kontynuując leczenie miejscowe i pielęgnację skóry, a w przypadku nawrotu choroby ponownie zastosować lek w skutecznej poprzednio dawce. U niektórych pacjentów może być konieczne kontynuowanie leczenia podtrzymującego przez dłuższy czas (> 6 miesięcy).

Osoby chorujące na AZS cechują się skłonnością do zakażeń bakteryjnych i wirusowych. Za główną przyczynę, poza defektem bariery naskórkowej, uznaje się obecnie zmniejszoną produkcję peptydów przeciwbakteryjnych w naskórku chorych na AZS, $\mathrm{w}$ tym $\beta$-defensyny i ludzkiej katelicydyny (LL-37) $[14,15]$. W związku z tym mogą pojawić się obawy, że zastosowanie w AZS cyklosporyny A, która jest lekiem immunosupresyjnym, zwiększa istotnie ryzyko wystąpienia zakażeń skórnych. Dotychczasowe badania wskazują jednak, że leczenie ciężkich postaci AZS cyklosporyną A jest bezpieczne zarówno u dorosłych, jak i dzieci, cechuje się dużą skutecznością i prowadzi 
ry activity, in patients with AD cyclosporin A induces an anti-pruritic effect, probably by inhibiting the secretion of pro-inflammatory cytokines including IL-2 and IL-31, and also by reducing the expression of cytokine receptors in the neurons of the paravertebral ganglia $[18,19]$.

However, a certain degree of caution is advised when cyclosporin A is used in patients with symptoms of active infection. According to the summary of product characteristics for cyclosporin A, active herpes simplex infections should be allowed to clear before treatment with cyclosporin A is initiated, however there is no need to discontinue the drug if herpes simplex infection occurs during the treatment, unless the infection is severe [20]. Staphylococcus aureus infections of the skin, which are common in AD, are not an absolute contraindication to using cyclosporin $\mathrm{A}$, provided that an effective antibiotic therapy is introduced concurrently. It is also important to note that during cyclosporin A treatment patients should avoid macrolide antibiotics, as they can increase the concentration of cyclosporin in blood [20].

\section{CONCLUSIONS}

Cyclosporin A remains the first-line drug in the treatment of severe forms of AD. The drug is fast-acting and highly effective, and contributes to a significant improvement in the quality of life of patients with AD. Properly used, cyclosporin A is not associated with a high risk of adverse reactions in patients with AD.

\section{CONFLICT OF INTEREST}

The paper was prepared based on the cooperation with TEVA Poland. do istotnej poprawy jakości życia pacjentów [16, 17]. Efekt terapeutyczny jest $\mathrm{z}$ reguły widoczny już po 2 tygodniach leczenia [17]. Ponadto u pacjentów z AZS cyklosporyna A, poza działaniem przeciwzapalnym, wywołuje także efekt przeciwświądowy, prawdopodobnie poprzez hamowanie uwalniania cytokin prozapalnych, w tym IL-2 i IL-31, jak również poprzez zmniejszenie ekspresji receptorów cytokinowych w neuronach zwojów przykręgosłupowych [18, 19].

Podczas stosowania cyklosporyny A u chorych z objawami czynnej infekcji należy zachować pewną ostrożność. Zgodnie z charakterystyką produktu leczniczego w przypadku obecności czynnego zakażenia wirusem opryszczki powinno się je wyleczyć przed rozpoczęciem podawania cyklosporyny A, jeśli natomiast opryszczka wystąpi w czasie leczenia, nie ma konieczności odstawienia leku, chyba że zakażenie jest ciężkie [20]. Zakażenia skóry gronkowcem złocistym (Staphylococcus aureus), częste zjawisko w AZS, nie są bezwzględnym przeciwwskazaniem do stosowania cyklosporyny A, pod warunkiem jednoczesnego wdrożenia skutecznej antybiotykoterapii. Podczas leczenia cyklosporyną A należy unikać antybiotyków z grupy makrolidów, gdyż mogą one zwiększać stężenie tego leku we krwi [20].

\section{WNIOSKI}

Cyklosporyna A jest lekiem pierwszego wyboru w terapii ciężkich postaci AZS. Cechuje się szybkim działaniem, dużą skutecznością, istotnie poprawia jakość życia chorych na AZS, a jeśli jest stosowana właściwie, ewentualne ryzyko wystąpienia działań niepożądanych wśród chorych na AZS jest małe.

\section{KONFLIKT INTERESÓW}

Praca powstała $\mathrm{w}$ ramach współpracy z firmą Teva Polska.

\section{References}

\section{Piśmiennictwo}

1. Palmer C.N., Irvine A.D., Terron-Kwiatkowski A., Zhao Y., Liao H., Lee S.P., et al.: Common loss-of-function variants of the epidermal barrier protein filaggrin are a major predisposing factor for atopic dermatitis. Nat Genet 2006, 38, 441-446.

2. Kim Y.M., Kim J., Han Y., Jeon B.H., Cheong H.K., Ahn K.: Short-term effects of weather and air pollution on atopic dermatitis symptoms in children: a panel study in Korea. PLoS One 2017, 12, e0175229.

3. Tang K.T., Ku K.C., Chen D.Y., Lin C.H., Tsuang B.J., Chen Y.H.: Adult atopic dermatitis and exposure to air pollutant a nationwide population-based study. Ann Allergy Asthma Immunol 2017, 118, 351-355.

4. Hidaka T., Ogawa E., Kobayashi E.H., Suzuki T., Funayama R., Nagashima T., et al.: The aryl hydrocarbon receptor AhR links atopic dermatitis and air pollution via induction of the neurotrophic factor artemin. Nat Immunol 2017, 18, 64-73.

5. Kim E.H., Kim S., Lee J.H., Kim J., Han Y., Kim Y.M., et al.: Indoor air pollution aggravates symptoms of atopic dermatitis in children. PLoS One 2015, 10, e0119501.

6. Hanifin J.M., Rajka G.: Diagnostic features of atopic dermatitis. Acta Derm Venereol Suppl (Stockh) 1980, 92, 44-47.

7. Nowicki R., Trzeciak M., Wilkowska A., Sokołowska-Wojdyło M., Lugowska-Umer H., Barańska-Rybak W., et al.: Atopic dermatitis: current treatment guidelines. Statement of the experts of the Dermatological Section, Polish Society of Allergology, and the Allergology Section, Polish Society of Dermatology. Postep Dermatol Alergol 2015, 32, $239-249$. 
8. Blauvelt A., de Bruin-Weller M., Gooderham M., Cather J.C., Weisman J., Pariser D., et al.: Long-term management of moderate-to-severe atopic dermatitis with dupilumab and concomitant topical corticosteroids (LIBERTY AD CHRONOS): a 1-year, randomised, double-blinded, placebo-controlled, phase 3 trial. Lancet 2017, 389, $2287-2303$.

9. Ruzicka T., Hanifin J.M., Furue M., Pulka G., Mlynarczyk I., Wollenberg A., et al.: Anti-interleukin-31 receptor A antibody for atopic dermatitis. N Engl J Med 2017, 376, 826-835.

10. Popovic B., Breed J., Rees D.G., Gardener M.J., Vinall L.M., Kemp B., et al.: Structural characterisation reveals mechanism of IL-13-neutralising monoclonal antibody tralokinumab as inhibition of binding to IL-13Ralpha1 and IL-13Ralpha2. J Mol Biol 2017, 429, 208-219.

11. Simon D., Bieber T.: Systemic therapy for atopic dermatitis. Allergy 2014, 69, 46-55.

12. Ko K.C., Tominaga M., Kamata Y., Umehara Y., Matsuda H., Takahashi N., et al.: Possible antipruritic mechanism of cyclosporine A in atopic dermatitis. Acta Derm Venereol 2016, 96, 624-629.

13. Roekevisch E., Spuls P.I., Kuester D., Limpens J., Schmitt J.: Efficacy and safety of systemic treatments for moderate-to-severe atopic dermatitis: a systematic review. J Allergy Clin Immunol 2014, 133, 429-438.

14. Ong P.Y., Ohtake T., Brandt C., Strickland I., Boguniewicz M., Ganz T., et al.: Endogenous antimicrobial peptides and skin infections in atopic dermatitis. N Engl J Med 2002, 347, 1151-1160.

15. Chieosilapatham P., Ogawa H., Niyonsaba F.: Current insights into the role of human beta-defensins in atopic dermatitis. Clin Exp Immunol 2017, doi: 10.1111/cei.13013 [Epub ahead of print].

16. Czech W., Bräutigam M., Weidinger G., Schöpf E.: A body-weight-independent dosing regimen of cyclosporine microemulsion is effective in severe atopic dermatitis and improves the quality of life. J Am Acad Dermatol 2000, 42, 653-659.

17. Griffiths C.E., Katsambas A., Dijkmans B.A., Finlay A.Y., Ho V.C., Johnston A., et al.: Update on the use of ciclosporin in immune-mediated dermatoses. Br J Dermatol 2006, 155 Suppl 2, 1-16.

18. Otsuka A., Tanioka M., Nakagawa Y., Honda T., Ikoma A., Miyachi Y., et al.: Effects of cyclosporine on pruritus and serum IL-31 levels in patients with atopic dermatitis. Eur J Dermatol 2011, 21, 816-817.

19. Ko K.C., Tominaga M., Kamata Y., Umehara Y., Matsuda H., Takahashi N., et al.: Possible antipruritic mechanism of cyclosporine A in atopic dermatitis. Acta Derm Venereol 2016, 96, 624-629.

20. Cyklosporyna A - charakterystyka produktu leczniczego. Available at: http://leki.urpl.gov.pl/files/25_Equoral_kap_ ela_25_50_100.pdf; accessed: 1.08.2017.

Received: 22.07.2017

Accepted: 5.08.2017

Otrzymano: 22.07.2017 r

Zaakceptowano: $5.08 .2017 \mathrm{r}$

How to cite this article

Kaaz K., Reich A.: Treatment of atopic dermatitis with cyclosporin A: a case report. Dermatol Rev/Przegl Dermatol 2017, 104, 432-438. DOI: https://doi.org/10.5114/dr.2017.69950. 